\title{
PENGARUH KOMPETENSI MANAJERIAL KEPALA SEKOLAH, LINGKUNGAN, MOTIVASI GURU, TERHADAP PRESTASI SISWA SMA MUHAMMADIYAH KOTA YOGYAKARTA
}

\author{
Arif Jamali, Lantip Diat Prasojo \\ SMA Muhammadiyah 3 Yogyakarta, Pascasarjana Universitas Negeri Yogyakarta \\ arifjamali_76@yahoo.com, lantip1975@gmail.com
}

\begin{abstract}
Abstrak
Penelitian ini bertujuan untuk mengungkapkan: (1) pengaruh langsung dan tidak langsung kompetensi manajerial kepala sekolah dengan prestasi belajar siswa kompetensi manajerial kepala sekolah dengan prestasi belajar siswa melalui motivasi berprestasi guru; (2) pengaruh langsung dan tidak langsung antara lingkungan sekolah dengan prestasi belajar siswa melalui motivasi berprestasi guru; (3) pengaruh langsung antara motivasi berprestasi guru dengan prestasi belajar siswa.

Penelitian ini merupakan penelitian ex-post facto, dengan populasi 318 guru SMA Muhammadiyah Kota Yogyakarta dan sampel 200 orang yang dipilih dengan teknik proportional sampling. Instrumen pengumpulan data berupa kuesioner. Analisis data menggunakan teknik analisis jalur untuk menguji hipotesis penelitian.

Hasil penelitian menunjukkan bahwa: (1) terdapat pengaruh langsung dan tak langsung kompetensi manajerial kepala sekolah dengan prestasi belajar siswa, dengan sumbangan efektif 5,52\% dengan prestasi belajar siswa melalui motivasi berprestasi guru, (sumbangan efektif sebesar 32,09\%); (2) tidak terdapat pengaruh langsung antara lingkungan sekolah dengan prestasi belajar siswa; (3) terdapat pengaruh tidak langsung antara lingkungan sekolah dengan prestasi belajar siswa melalui motivasi berprestasi guru, (sumbangan efektif sebesar 1,04\%); (4) terdapat pengaruh langsung antara motivasi berprestasi guru dengan prestasi belajar siswa, (sumbangan efektif sebesar 47,06\%). Jadi secara keseluruhan sumbangan yang diberikan oleh kompetensi manajerial kepala sekolah, lingkungan sekolah, motivasi berprestasi guru baik secara langsung maupun tidak terhadap prestasi belajar siswa sebesar $85,71 \%$. Hal ini berarti jika kompetensi manajerial kepala sekolah, lingkungan sekolah dan motivasi berprestasi guru ditingkatkan kualitasnya maka akan berkontribusi positif terhadap peningkatan prestasi belajar siswa SMA Muhammadiyah Kota Yogyakarta.
\end{abstract}

Kata Kunci: kompetensi manajerial kepala sekolah, lingkungan sekolah, motivasi berprestasi guru, prestasi belajar siswa 


\title{
THE EFFECT OF MANAGERIAL COMPETENCIES OF SCHOOL PRINCIPALS, SCHOOL ENVIRONMENT, TEACHERS' ACHIEVEMENT MOTIVATION ON THE ACHIEVEMENT OF THE STUDENTS OF SMA MUHAMMADIYAH IN YOGYAKARTA
}

\begin{abstract}
This research aims to reveal: (1) the direct and indirect effect of managerial competence of school principals on the achievement of the students; through teachers' achievement motivation; (2) the direct effect of school environtment on students' achievement; (3) the indirect effect of school environment on students' achievement through teachers' achievement motivation; (4) the direct effect of teachers' achievement motivation on students' achievement

This research is an ex-post facto research with the population of 318 teachers of SMA Muhammadiyah in Yogyakarta and 200 teachers as the sample established using the proportional sampling technique. The instrument used for collecting the data was a questionnaire. The data were analysed using the path analysis technique to test the research hypothesis.

The findings of the research show that: (1) there is a direct effect of managerial competence of the school principals on the students' achievement, (5,52\% of effective contribution); (2) there is an indirect effect of managerial competence of the school principals on students' achievement through teachers' achievement motivation, (the effective contribution of 32,09\%); (3) there is no direct effect of school environtment on students' achievement; (4) there is an indirect effect of school environtment on student's achievement through teachers' achievement motivation, (the effective contribution of 1,04\%; (5) there is a direct effect of teachers' achievement motivation on students' achievement, as showed by the effective contribution of $47.060 \%$. With regard to this, the total effective contribution of managerial competence of the school principals, school environment, and teachers' achievement motivation either directly or indirectly to the students' achievement is $85.71 \%$. This means that if the quality of the managerial competence of the school principals, school environment, and teachers' achievement motivation is increased, it will give a positive contribution toward the improvement of the achievement of the students of SMA Muhammadiyah Kota Yogyakarta.
\end{abstract}

Keywords: managerial competence of the school principal, school environment, teachers' achievement motivation, students' achievement 


\section{Pendahuluan}

Kemajuan suatu bangsa sangat ditentukan oleh kualitas pendidikannya dan kualitas pendidikan berbanding lurus dengan tingkat kesejahteraan masyarakat, semakin baik mutu dan kualitas pendidikan maka semakin maju bangsa tersebut. Pendidikan adalah investasi kemanusiaan (human investment) jangka panjang, yang hasilnya tidak mungkin dirasakan seketika, akan tetapi baru terasa di masa-masa yang akan datang. Jika kita ingin memprediksi seperti apa kondisi suatu bangsa di masa yang akan datang maka analisislah kualitas pendidikannya saat ini.

Di dalam UU Nomor 20 tahun 2003 tentang Sistem Pendidikan Nasional Bab II pasal 3 disebutkan bahwa: Pendidikan $\mathrm{Na}$ sional berfungsi mencerdaskan, mengembangkan kemampuan dan membentuk watak serta peradaban bangsa yang bermanfaat dalam rangka mencerdaskan kehidupan bangsa, bertujuan untuk berkembangnya potensi peserta didik agar menjadi manusia yang beriman dan bertakwa kepada Tuhan Yang Maha Esa berakhlaq mulia, sehat, berilmu, cakap, kreatif, mandiri dan menjadi warga negara yang demokratis serta bertanggung jawab.

Menurut Suyanto (2006, p.7) bahwa untuk menciptakan keunggulan kompetitif, bangsa Indonesia memerlukan inovasi yang pesat dalam dunia pendidikan, dengan keunggulan dan kualitas pendidikan diharapkan dapat mengangkat harkat dan martabat bangsa di era globalisasi ini. Usaha peningkatan pendidikan bermuara pada sekolah yang merupakan institusi paling depan dalam menjalankan proses pendidikan, dengan logika ini maka sekolah menjadi salah satu penentu kualitas pendidikan di Indonesia, atau dengan kata lain jika sekolah berkualitas maka memberi sumbangan besar pada kualitas pendidikan di Indonesia.

Tujuan dari proses pembelajaran di sekolah adalah prestasi belajar siswa, artinya salah satu indikator mutu sekolah yang baik jika prestasi belajar siswanya baik. Prestasi belajar siswa sebagai hasil dari proses pendidikan di sekolah sangat tergantung pada pelaku utama yang sangat penting yaitu kepala sekolah dan guru. Kepala sekolah adalah seorang tenaga fungsional guru yang diberikan tugas untuk memimpin suatu sekolah dimana diselenggarakannya proses belajar mengajar atau tempat dimana terjadi interaksi antara guru yang memberikan pelajaran dan murid yang menerima pelajaran. Menurut Enco Mulyasa (2011, p.24). Kepala sekolah adalah salah satu komponen pendidikan yang paling berperan dalam meningkatkan kualitas pendidikan.

Selain kompetensi manajerial kepala sekolah yang berpengaruh pada prestasi belajar siswa, motivasi untuk berprestasi guru juga sangat berpengaruh pada peningkatan prestasi belajar siswa. Seseorang yang memiliki motivasi kerja yang kuat, akan memiliki banyak energi untuk melakukan suatu kegiatan. Motivasi mendorong seseorang untuk bertindak melakukan sesuatu (Ngalim Purwanto, 2011, p.60). Motivasi dapat bersumber dari dalam diri sendiri (motivasi internal) dan dari luar diri (motivasi eksternal). Motivasi kerja yang baik, bilamana timbul dari keinginan dalam diri seseorang untuk melakukan aktivitas. Apabila seseorang memiliki motivasi internal dalam dirinya, maka ia akan bekerja dengan baik, bahkan tidak memerlukan motivasi dari luar untuk mendorong dia bekerja. Dalam menjalankan aktivitas, motivasi internal sangat diperlukan, terutama untuk belajar sendiri. Guru yang mempunyai motivasi berprestasi yang tinggi, tentu dalam bekerja akan melaksanakan segala tugasnya dengan sebaik-baiknya, yang pada akhirnya akan berpengaruh pada berjalannya proses belajar mengajar dan dapat meningkatkan prestasi belajar siswa. Berdasarkan paparan di atas dapat dikatakan bahwa kepemimpinan kepala sekolah, kompetensi manajerial dan motivasi kerja guru yang tinggi akan dapat meningkat-kan prestasi belajar siswa.

Di sisi lain lingkungan kerja yang kondusif akan banyak berpengaruh pada prestasi belajar siswa. Lingkungan kerja 
yang kondusif sangat dibutuhkan bagi guru untuk menumbuhkan dorongan dalam diri guru tersebut untuk bekerja lebih bersemangat. Ini berarti bahwa lingkungan kerja sekolah berpengaruh terhadap tinggi rendahnya motivasi para guru yang pada akhirnya berpengaruh pada prestasi belajar siswa. Sebuah organisasi hanya akan berkembang dengan baik jika ditunjang dengan lingkungan kerja yang kondusif. Di sekolah, kepala sekolah bertanggung jawab terhadap penciptaan lingkungan kerja tersebut. Anwar Prabu Mangkunegara (2008, p.105), menjelaskan bahwa lingkungan kerja atau kondisi kerja adalah semua aspek fisik kerja, psikologis kerja, dan peraturanperaturan kerja yang dapat mempengaruhi kepuasan kerja dan pencapaian produktivitas kerja. Kutipan tersebut memberikan pengertian terutama kepada para pemimpin organisasi termasuk organisasi pendidikan, untuk selalu memperhatikan lingkungan kerja sekolah. Pemimpin harus berusaha mengelola lingkungan kerja sekolah, agar dapat menciptakan suasana yang dapat menumbuhkan semangat dan kegairahan kerja para guru, melalui suasana yang demikian guru akan merasa tenang, nyaman, tidak ada yang ditakuti dalam bekerja sehingga kinerjanya meningkat. Penelitian ini bertujuan untuk mengungkapkan: (1) pengaruh langsung maupun tidak langsung kompetensi manajerial kepala sekolah terhadap prestasi belajar siswa; (2) pengaruh langsung maupun tidak langsung lingkungan sekolah terhadap prestasi belajar siswa; (3) pengaruh langsung motivasi berprestasi guru terhadap prestasi belajar siswa SMA Muhammadiyah Kota Yogyakarta.

\section{Prestasi Belajar Siswa}

Menurut Kamus Besar Bahasa Indonesia prestasi adalah hasil pelajaran yang diperoleh dari kegiatan belajar di sekolah atau perguruan tinggi yang bersifat kognitif dan biasanya ditentukan melalui pengukuran dan penilaian. Menurut Aan Komariah \& Cepi Triatna (2006, pp.34-35) mengemukakan bahwa prestasi menjadi tujuan sekolah. Sekolah efektif adalah sekolah yang membuat prestasi tidak hanya pada siswa tetapi pada semua komponen sekolah, namun indikator yang paling utama adalah prestasi siswa. Prestasi siswa yang dimaksud bukan hanya unggul dalam kecerdasaan kognitif belaka tetapi juga pada aspek afektif dan psikomotorik. Hal senada juga diungkapkan Mortimore (Suyanto, 2006, p.122) "One in which students progress further than might be expected from a consideration of intake." Nampak jelas bahwa tugas sekolah tidak hanya pencapaian prestasi sebagian kecil siswa, akan tetapi menjaga agar semua siswa dapat berkembang sejauh mungkin, jika dibandingkan dengan kondisi awal pembelajaran.

Menurut Nidds \& Mc Gerald (Michael, et al, 1996, p.1)

What are the characteristics of a successful student? While the definition of "successful student" has changed over the years, today's youth need to know a great deal more than reading, writing, and arithmetic in order to succeed. According to key business leaders in the US, students who are to succeed in 21st century America must be: (1). able to analyze, synthesize, and evaluate information; (2) able to effectively communicate with others; (3) proficient in science, mathematics, computer/technical skills, foreign languages, as well as history, geography, and global awareness; (4) capable of collaboratively working in culturally diverse settings; (5) leaders who see projects through to completion; (6) responsible decision makers who are self-motivated and active political participants; and (7) ethical individuals who are committed to their families, communities, and colleagues.

Arti dari pernyataan tersebut adalah siswa yang berprestasi adalah: 1) mampu menganalisis, mensintesis, dan mengevaluasi informasi; 2) mampu berkomunikasi secara efektif dengan orang lain; 3) menguasai ilmu pengetahuan, matematika, komputer/keterampilan teknis, bahasa asing, serta sejarah, geografi, dan kesadaran global; 4) mampu bekerja secara 
kolaboratif dalam setting budaya yang beragam; 5) memimpin proyek-proyek sampai selesai; 6) bertanggung jawab, dan 7) memiliki etika individu yang baik. Menurut Nurkencana (2005, p.62) mengemukakan bahwa prestasi belajar adalah hasil yang telah dicapai atau diperoleh anak berupa nilai mata pelajaran. Ditambahkan bahwa prestasi belajar merupakan hasil yang mengakibatkan perubahan dalam diri individu sebagai hasil dari aktivitas dalam belajar. Dari pengertian di atas dapat dipahami bahwa prestasi belajar adalah hasil kemampuan seseorang pada bidang tertentu dalam mencapai tingkat kompetensi tertentu yang dapat secara langsung diukur dengan tes. Hasil belajar merupakan perubahan tingkah laku peserta didik setelah bertambah pengetahuannya.

Faktor-faktor yang memperngaruhi prestasi belajar adalah faktor intern yaitu faktor yang berasal dari dalam diri individu yang sedang belajar. Adapun yang termasuk di dalam faktor intern diantaranya adalah: (1) Badan sehat yang berarti segenap badan terbebas dari penyakit. Kesehatan seseorang sangat berpengaruh terhadap prestasi belajarnya. (2) Intelegensi; (3) Perhatian; (4) Minat; (5) Bakat; (6) Motivasi; (7) Kematangan.; (8) Kesiapan. Disisi lain ada faktor ekstern yang merupakan faktor yang ada di luar siswa. Ada beberapa faktor ekstern yang berpengaruh: (1) faktor keluarga, (2) faktor sekolah, (3) faktor Masyarakat.

\section{Kompetensi Manajerial Kepala Sekolah}

Kompetensi pada hakekatnya adalah kemampuan seseorang untuk melakukan suatu pekerjaan, berupa kegiatan, perilaku yang hasilnya dapat ditunjukkan dan dapat diukur tingkat keberhasilannya (User Usman, 2011, p.14). Untuk mengerjakan pekerjaan tersebut seseorang harus mempunyai kemampuan baik berupa pengetahuan, keterampilan, maupun sikap yang sesuai dengan bidang pekerjaannya. Kompetensi disamping menentukan perilaku dan kinerja seseorang juga menentukan apakah seseorang melakukan pekerjaannya dengan baik berdasarkan standar kriteria yang telah ditentukan.

Manajerial merupakan kata sifat yang asal katanya adalah manajemen. Manajer adalah orang yang melakukan kegiatan manajemen. Pemahaman ini dapat ditelusuri dari pendapat para ahli berikut ini. Menurut Ernie Tisnawati Sule \& Saeful Kurniawan (2008, p.2) manajer adalah individu yang bertanggung jawab secara langsung untuk memastikan kegiatan dalam sebuah organisasi dijalankan bersama para anggota dari organisasi. Stewart (Boddy, 2008, p.10) mengungkapkan tentang manajer

"... as someone who gets things done with the aid of people and other resources, which leads to a definition of management as the activity of getting things done with the aid of people and other resources. So described, management is a feature of most human circumstances domestic, social and political - as well as in formally established organi-sations."

Rosemary Stewart menggambarkan seorang manajer adalah seseorang yang melakukan sesuatu dengan bantuan orang lain dan sumber daya lainnya yang mengarah pada definisi manajemen. Sedangkan Armstrong, (2009, p.15) menjelaskan bagaimana seorang manajer tersebut:

"Managers are there to get results by ensuring that their function, unit or department operates effectively. They manage people and their other resourcesfinance, facilities, knowledge, information, time and themselves. They are accountable for attaining goals, having been given authority over those working in their unit or department. Accountability means that they are responsible (held to account) for what they do and what they achieve. Authority means having the right or power to get people to do things. Authority is exercised through leadership and personal influence arising from position, personality and knowledge.

Pernyataan di atas menunjukkan bahwa manajer memastikan fungsi setiap unit/departemen berjalan secara efektif, untuk itu manajer melakukan pengelolaan 
atas sumber daya yang ada, baik sumber daya manusia, keuangan, fasilitas, informasi, waktu, dan bertanggung jawab atas ketercapaian tujuan. Seorang manajer selain diberi tanggung jawab juga diberi otoritas, yang berarti mempunyai hak untuk atau kekuasaan untuk mengatur orang-orang di sekelilingnya. Otoritas dilaksanakan melalui kepemimpinan dan pengaruh pribadi yang timbul dari posisi, kepribadian dan pengetahuan.

Seorang manajer dalam hal ini kepala sekolah, di samping harus mampu melaksanakan proses manajemen yang merujuk pada fungsi-fungsi manajemen, juga harus memahami sekaligus menerapkan substansi kegiatan pendidikan. Kepala sekolah mampu melakukan fungsi-fungsi manajemen dengan baik, meliputi:

perencanaan; (2) pengorganisasian; (3) pengarahan/pengendalian; dan (4) pengawasan. Peran manajerial kepala sekolah menurut Katz dan Kahn (Lunenburg \& Ornstien 2000, p.333) dibagi tiga yakni : (1) Technical, involving good planning, organizing, coordinating, supervising, and controlling techniques; (2) Human, dealing with human relations and people skills, good motivating and morale building skills; and (3) Conceptual, emphasizing knowledge and technical skills related to the service (or product) of the organization. Katz dan Kahn membagi keahlian manajemen menjadi tiga area utama: pertama teknis, melibatkan perencanaan yang baik, pengorganisasian, koordinasi, pengawasan, dan teknik pengawasan; kedua hubungan antarmanusia, yang berurusan dengan hubungan antarmanusia dan keterampilan orangorang, baik memotivasi dan semangat membangun keterampilan, dan ketiga konseptual, menekankan pengetahuan dan keterampilan teknis yang terkait dengan layanan (atau produk) dari organisasi. Keterampilan manajerial diperlukan untuk melaksanakan tugas manajerial secara efektif.

Lingkungan Sekolah

Lingkungan menurut Ngalim Purwanto (2011, p.28) meliputi semua kondisi dalam dunia yang mempengaruhi tingkah laku kita, pertumbuhan, perkembangan manusia. Oemar Hamalik (2008, p.98) mengungkapkan bahwa antara individu dan lingkungan terjalin proses interaksi atau saling mempengaruhi satu dengan lainnya. Tingkah laku dapat mempengaruhi lingkungan baik positif maupun negatif. Dikatakan positif jika tingkah laku tersebut membawa dampak yang baik bagi lingkungan; begitu juga sebaliknya dikatakan negatif karena membawa pengaruh buruk bagi lingkungan. Disisi lain lingkunganpun dapat membawa pengaruh pada pola tingkah laku individu.

Lingkungan merupakan salah satu penyebab dari keberhasilan dalam melaksanakan tugas, apabila seorang pekerja mendapat pengaruh yang positif, maka pekerja tersebut akan mempunyai moral yang lebih baik dalam melakukan pekerjaannya, dan ini berarti akan meningkat efisiensi dalam pencapaian suatu tujuan. Sedangkan apabila seorang pekerja mendapat pengaruh yang negatif, maka pekerja tersebut akan mengalami kemerosotan moral dalam bekerja dan akibatnya akan terjadi suatu pemborosan-pemborosan atau pengeluaran biaya yang lebih banyak dibandingkan dengan biaya yang semestinya dikeluarkan. menurut McNergney \& Carrier (1981, p.177) mendefinisikan "Any educational environment is a set of external conditions designed to help people learn". Pernyataan tersebut menjelaskan bahwa lingkungan pendidikan adalah seperangkat kondisi eksternal yang dirancang untuk membantu seseorang untuk belajar. Kondisi tersebutlah yang kemudian disebutkan dengan lingkungan. Lingkungan sekolah dapat dibagi dalam dua hal: pertama lingkungan fisik. Lingkungan fisik sekolah dapat ditemui baik di dalam sekolah maupun di luar sekolah. Lingkungan fisik di dalam sekolah merupakan semua sarana fisik sekolah yang dapat menunjang kelancaran proses pendidikan di sekolah, misalkan gedung, perpustakaan, ruang kelas, kamar kecil, halaman sekolah, aula, labotarorium, tempat ibadah dan lain sebagiannya. Menurut WHO (2002, p.1) 
The physical school environment encompasses the school building and all its contents including physical structures, infrastructure, furniture, and the use and presence of chemicals and biological agents; the site on which a school is located; and the surrounding environment including the air, water, and materials with which children may come into contact, as well as nearby land uses, roadways and other hazards.

Lingkungan fisik sekolah menurut WHO di atas meliputi gedung sekolah dan seluruh isinya termasuk struktur fisik, infrastruktur, furniture, penggunaan bahan kimia, taman hayati, dan lingkungan sekitar termasuk air, udara, dan jalan raya menuju sekolah.

Menurut Schneider (2002, p.16) dari salah satu kesimpulan hasil risetnya menjelaskan bahwa :

School facilities affect learning. Spatial configurations, noise, heat, cold, light, and air quality obviously bear on students' and teachers' ability to perform. Empirical studies will continue, focusing on fine-tuning the acceptable ranges of these variables for optimal academic outcomes. But we already know what is needed: clean air, good light, and a quiet, comfortable, and safe learning environment. This can be and generally has been achieved within the limits of existing knowledge, technology, and materials. It simply requires adequate funding and competent design, construction, and maintenance.

Kesimpulan hasil riset tersebut mengandung makna bahwa fasilitas sekolah sangat berpengaruh pada performa hasil belajar siswa. Kondisi gedung, kualitas udara, dan penerangan semuanya mempengaruhi kinerja guru maupun siswa. Oleh karena itu semua bentuk fasilitas sekolah harus dioptimalkan untuk meningkatkan kinerja akademik sekolah. Pernyataan ini didukung oleh berbagai penelitian yang pernah ada.

Kedua lingkungan sosial adalah semua orang atau manusia lain yang dapat mempengaruhi manusia lain. Pengaruh lingkungan sosial itu ada yang diterima secara langsung dan ada yang tidak langsung. Pengaruh secara langsung seperti dalam pergaulan sehari-hari dengan orang lain, keluarga, teman-teman, kawan sekolah, sepekerjaan, dan lain sebagainya. Pengaruh yang tidak langsung yaitu: melalui radio, TV majalah, buku-buku surat kabar dan lain sebagainya (Ngalim Purwanto, 2011, p.29). Lingkungan sosial dalam hal ini masyarakat dapat menjadi bahan pelajaran bagi siswa. Menurut Oemar Hamalik (2008, p.99) ada banyak manfaat mempelajari masyarakat sebagai lingkungan pendidikan bagi peserta didik antara lain: (1) menanamkan pengertian yang realistik tentang proses-proses sosial dalam kehidupan; (2) mengembangkan kesadaran dan sensitif terhadap masalahmasalah sosial; (3) merupakan latihan berfikir ilmiah berdasarkan fakta yang ada di masyarakat; (4) mendorong rasa tanggung jawab terhadap masyarakat; (5) mempersiapkan peserta didik ke arah kehidupan masyarakat, dan (6) mengembangkan kemampuan dan kebiasaan observasi di kalangan peserta didik.

\section{Motivasi Berprestasi}

Kata Motivasi berasal dari kata Latin "Motivum" yang berarti dorongan, daya penggerak atau kekuatan yang terdapat dalam diri yang menyebabkan seseorang bertindak atau berbuat. Selanjutnya diserap dalam bahasa Inggris motivation berarti pemberian motif, penimbulan motif atau hal yang menimbulkan dorongan atau keadaan yang menimbulkan dorongan (Sri Esti Wuryani Djiwandono, 2009, p.329). Sedangkan Irwanto (2002, p.193) mengungkapkan bahwa motivasi adalah penggerak perilaku atau penentu perilaku, dengan kata lain motivasi adalah suatu kontruk teoritis mengenai terjadinya perilaku. Lebih lanjut Irwanto (2002, p.195) menggambarkan tentang daur motivasi disajikan seperti pada Gambar 1. 


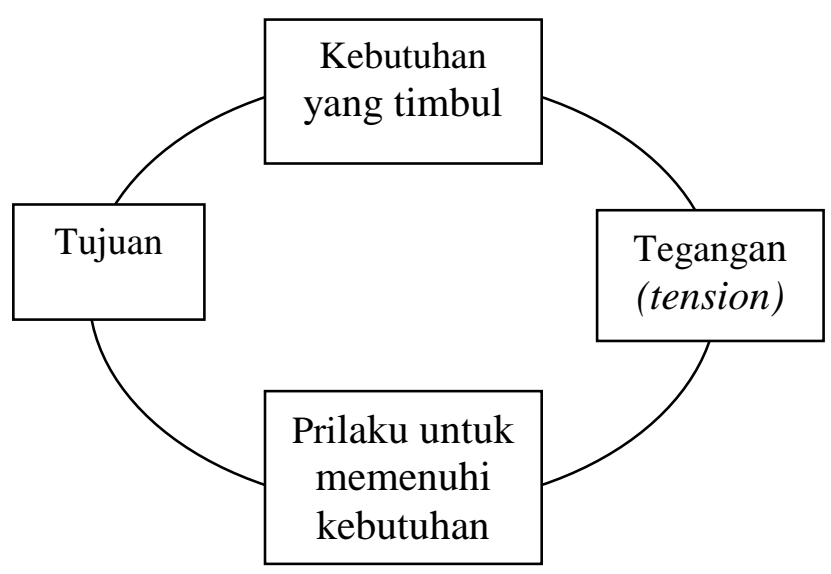

Gambar 1. Daur Motivasi

(Sumber : Irwanto, 2002, p.195)

Kebutuhan manusia akibat dari determinan tertentu akan menimbulkan ketegangan dan ini mendorong perilaku untuk memenuhi kebutuhan tersebut, jika kebutuhan tersebut sudah dipenuhi maka ketegangan akan melemah sampai munculnya ketegangan baru dikarenakan munculnya kebutuhan baru, begitu seterusnya yang kemudian disebut sebagai daur motivasi. Menurut Miner (Lunenburg \& Ornstein, 2000, p.88) mendifiniskan motivasi sebagai berikut "motivation has been defined as those processes within an individual that stimulate behavior and channel it in ways that should benefit the organization as a whole". Definisi ini mengisyaratkan bahwa motivasi sebagai proses dalam individu yang merang-sang perilaku dan menyalurkannya sehingga menguntungkan organisasi secara keseluruhan.

Motivasi berprestasi menurut McClelland (Husaini Usman, 2011, p.264) diartikan sebagai suatu dorongan yang muncul karena adanya suatu rangsang (stimulus) yang menggerakkan individu untuk dapat menyelesaikan suatu tugas dengan lebih baik, lebih cepat, dan lebih efisien untuk mencapai prestasi yang diinginkan. Tiga kebutuhan McClelland adalah: (1) kebutuhan akan prestasi (need of achievement); (2) kebutuhan akan afiliasi (need of affiliation), dan (3) kebutuhan akan kekuasaan (need of power).

Menurut teori ini, seseorang yang mempunyai need of achievement yang tinggi selalu mempunyai pola berpikir tertentu ketika ia merencanakan untuk melaksanakan sesuatu, yaitu selalu mempertimbangkan pekerjaan yang akan dilakukan, lalu memikirkan kekuatan, peluang, dan ancaman yang mungkin dihadapi dalam mencapai tujuan tersebut dan menentukan strategi yang akan dilakukan. Ciri lain orang yang mempunyai need of achievement tinggi adalah kesediaannya untuk memikul tanggung jawab sebagai konsekuensi usahanya untuk mencapai tujuan, berani mengambil resiko yang sudah diperhitungkan, bersedia mencari informasi untuk mengukur kemajuannya, dan ingin kepuasan dari yang telah dikerjakannya (Husaini Usman, 2008, p.264). Lebih lengkap Husaini Usman (2008, p.264) menjabarkan ciri orang yang mempunyai motif berprestasi yang tinggi yaitu; (1) Bertanggung jawab atas segala perbuatannya, mengaitkan diri pada karier atau hidup masa depan, dan tidak menyalahkan orang lain dalam kegagalannya; (2) Berusaha mencari umpan balik atas segala perbuatannya, dan selalu bersedia mendengarkan pendapat orang lain sebagai masukan dalam memperbaiki dirinya; (3) Berani mengambil risiko dengan penuh perhitungan; (4) Berusaha melakukan sesuatu secara inovatif dan kreatif, banyak gagasan, dan mampu mewujudkan gagasannya dengan baik. (5) Pandai mengatur waktu, yang dapat dikerjakan sekarang tidak ditunda hari esok; (6) Bekerja keras dan bangga atas hasil yang telah dicapai.

Guru sebagai pendidik memiliki tugas dan tanggung jawab yang berat. Guru harus menyadari bahwa ia harus mengerjakan tugasnya tersebut dengan sungguh-sungguh, bertanggung jawab, ikhlas dan tidak asal-asalan, sehingga siswa dapat dengan mudah menerima apa saja yang disampaikan oleh gurunya yang pada akhirnya dapat meningkatkan prestasi belajar siswa.

Kerangka Pikir dan Hipotesis

Dalam kerangka pikir penelitian ini akan diteliti hubungan antara empat variabel yaitu kompetensi manajerial kepala sekolah yang diberi simbol X1, lingkungan 
kerja guru yang diberi simbol $\mathrm{X} 2$, motivasi berprestasi guru yang diberi simbol Y1 serta prestasi siswa yang diberi simbol Y2. Penelitian ini adalah penelitian korelasi yaitu mencari hubungan antara dua atau lebih variabel, teknik analisa data yang digunakan adalah teknik analisis jalur (Path analysis) yaitu menganalisa data yang terkumpul baik secara langsung maupun tidak langsung. Untuk lebih jelas hubungan antara keempat variabel dapat digambarkan sebagai berikut:

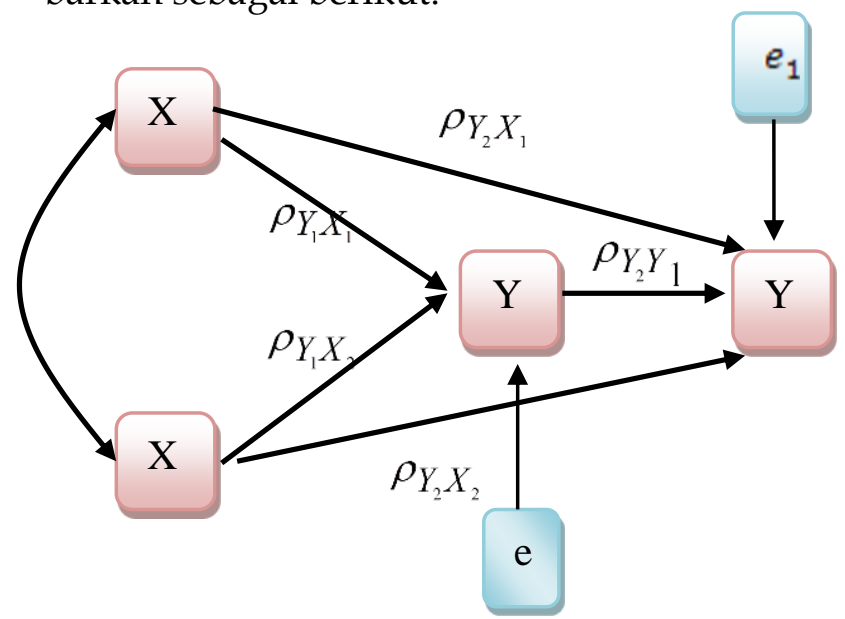

Gambar 2. Jalur Antarvariabel

\section{Metode}

Penelitian ini menggunakan pendekatan kuantitatif dan jenisnya adalah penelitian korelasional dengan rancangan expost facto karena penelitian ini tidak memberikan perlakuan atau memanipulasi perubahan khusus terhadap subjek penelitian. Keterangan-keterangan yang dihim- pun adalah keterangan yang berdasarkan kejadian atau pengalaman yang telah berlangsung, baik itu menyangkut kompetensi manajerial kepala sekolah, lingkungan sekolah, motivasi berprestasi guru, maupun prestasi siswa.

Populasi penelitian ini adalah kepala sekolah dan guru SMA Muhammadiyah di Kota Yogyakarta, karena populasinya cukup besar yaitu terdiri dari 7 SMA Muhammadiyah Kota Yogyakarta terdapat 7 kepala sekolah, 344 guru, maka diambillah sampel. Sampel untuk kepala sekolah diambil sebanyak populasi atau dengan kata lain sampel sama dengan populasi. Sedangkan sampel guru digunakan proportional Sampling, yaitu sampel yang dihitung berdasarkan perbandingan dengan sebanyak 200 sampel. Teknik pengumpulan data menggunakan angket, kemudian data dianalisis menggunakan analisis jalur dengan bantuan sofware program SPSS.17.

\section{Hasil}

Sebelum analisis data, terlebih dahulu dilakukan uji normalitas, linieritas, heteros-kedastisitas, dan uji multikolinieritas. Dari hasil uji yang dilakukan menunjukkan bahwa semua data telah memenuhi syarat untuk dilakukan uji hipotesis dengan menggunakan uji statistik. Adapun hasil uji statistik untuk melihat hubungan dan besaran koefisien jalur, maka analisis setiap blok di atas dapat dirangkum dalam Tabel 1.

Tabel 1. Hubungan Kausalitas Variabel Eksogen dengan Variabel Endogen

\begin{tabular}{|c|c|c|c|c|c|c|}
\hline Blok & Hubungan antarvariabel & Lambang & B & $\mathrm{T}$ & Sig & Ket \\
\hline \multirow[t]{2}{*}{1} & Kompetensi $\quad$ Manajerial $\quad$ Kepala & $\rho_{Y 1 X 1}$ & .681 & 13.256 & .000 & Signifikan \\
\hline & $\begin{array}{l}\text { Lingkungan Kerja dengan Motivasi } \\
\text { Berprestasi }\end{array}$ & $\rho_{\bigvee 1 X 2}$ & .103 & 2.000 & .047 & Signifikan \\
\hline \multirow[t]{2}{*}{2} & $\begin{array}{l}\text { Kompetensi } \quad \text { Manajerial } \quad \text { Kepala } \\
\text { Sekolah dengan prestasi belajar siswa }\end{array}$ & $\rho_{Y 2 X}$ & .235 & 4.701 & .000 & Signifikan \\
\hline & $\begin{array}{l}\text { Lingkungan Kerja dengan prestasi } \\
\text { belajar siswa }\end{array}$ & $\rho_{Y 2 \times 2}$ & $\begin{array}{r}- \\
.021\end{array}$ & -.578 & .564 & $\begin{array}{l}\text { Tidak } \\
\text { Signifikan }\end{array}$ \\
\hline 3 & $\begin{array}{l}\text { Motivasi Berprestasi dengan pres-tasi } \\
\text { belajar siswa }\end{array}$ & $\rho_{\mathrm{Y} 2 \mathrm{Y} 1}$ & .686 & 13.614 & .000 & Signifikan \\
\hline
\end{tabular}


Berdasarkan hasil pada Tabel 1 maka, tidak semua hubungan variabel eksogenus dengan variabel endogenus signifikan. Hubungan antara variabel lingkungan kerja dengan variabel prestasi belajar siswa dinyatakan tidak signifikan. Sehingga dapat dikatakan bahwa lingkungan kerja tidak mempunyai hubungan secara signifikan dengan prestasi belajar siswa SMA Muhammadiyah di Kota Yogyakarta. Untuk hubungan yang lain hasilnya adalah signifikan.

Selanjutnya menghitung sumbangan efektif masing-masing variabel disajikan dalam tabel 2.

Tabel 2. Sumbangan Efektif Variabel eksogen (langsung dan tidak langsung) terhadap prestasi belajar siswa

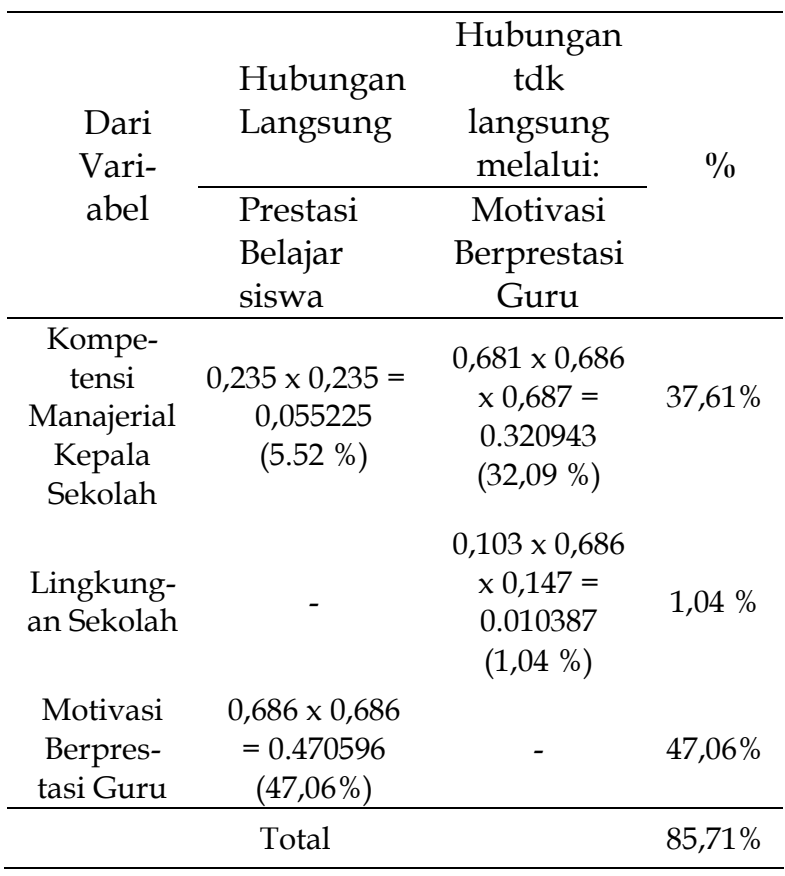

Berdasarkan hasil perhitungan sumbangan efektif seperti dalam tabel di atas, dapat dikemukakan bahwa 85,71\% variabel prestasi belajar siswa dapat dijelaskan atau diprediksi oleh variabel kompetensi manajerial kepala sekolah dan motivasi berprestasi guru. Variabel lingkungan kerja tidak memberikan sumbangan yang berarti baik secara langsung maupun tidak langsung untuk memprediksi prestasi belajar siswa. Sedangkan sebesar $14,29 \%$ variabel prestasi belajar siswa tidak dapat dijelaskan oleh variabel kompetensi manajerial kepala sekolah dan motivasi berprestasi guru, yang disebut dengan variabel residu, atau dengan kata lain bahwa variabel residu sebesar 14,29\%.

Selanjutnya sumbangan efektif sebesar $85,71 \%$ yang berasal dari variabel kompetensi manajerial kepala sekolah, lingkungan sekolah dan motivasi berprestasi guru dapat dilaporkan sesuai dengan urutan besar kecilnya konstribusi pada prestasi belajar siswa SMA Muhammadiyah Kota Yogyakarta. Melalui hubungan langsung kompetensi manajerial kepala sekolah memberikan sumbangan efektif sebesar 5,52\%, dan hubungan tidak langsung kompetensi manajerial kepala sekolah melalui motivasi berprestasi guru terhadap prestasi belajar siswa memberikan sumbangan efektif sebesar 32,09\%. Hubungan tidak langsung sekolah melalui motivasi berprestasi guru memberikan sumbangan efektif sebesar 1,04\%, dan motivasi berprestasi guru secara langsung memiliki sumbangan efektif terbesar yaitu $47,06 \%$, dan sebesar $14,29 \%$ tidak dapat diprediksi baik melalui variabel kompetensi manajerial kepala sekolah, lingkungan sekolah maupun motivasi berprestasi guru.

Berdasarkan temuan koefisien jalur sebagaimana yang terdapat dalam tabel di atas selanjutnya dapat disusun sebuah model gambar jalur hubungan antarvariabel penelitian. Model hubungan jalur-jalur hubungan tersebut hanyalah hubungan yang signifikan saja sedangkan jalur hubungan yang tidak signifikan tidak perlu digambar, dengan demikian model gambar ini sebagai hasil revisi, setelah dilakukan pengujian terhadap hubungan jalur-jalur variabel penelitian. Model dimaksud dapat dilihat pada Gambar 3. 


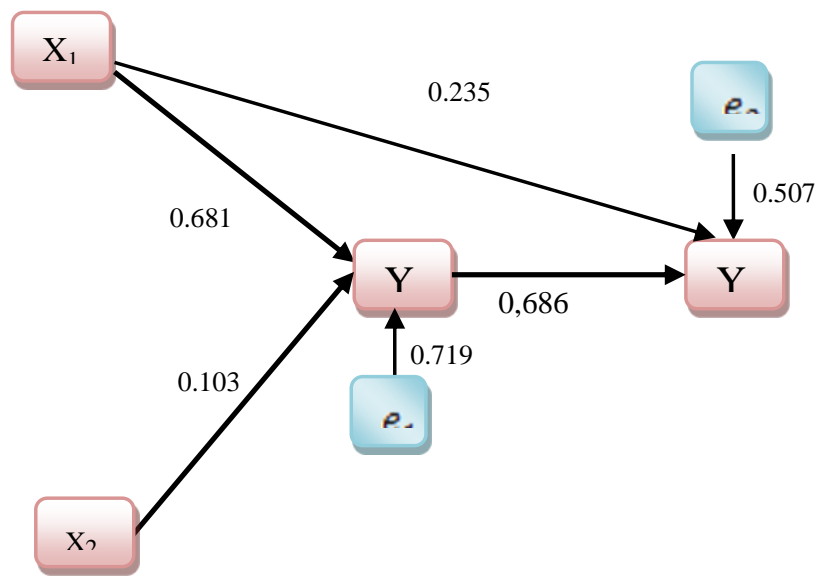

Gambar 3. Model empirik hubungan variabel-variabel penelitian

Setelah pengujian sesuai dengan tahap-tahap analisis jalur (Path analysis) model gambar konseptual hubungan variabel-variabel penelitian yang diajukan dalam gambar 1 akhirnya mengalami perubahan sehingga menjadi seperti yang tergambar pada gambar 2, Dapat dilihat pada gambar tersebut bahwa hubungan variabel eksogen kompetensi manajerial kepala sekolah mempunyai hubungan langsung maupun tidak langsung yang diperantarai oleh variabel motivasi berprestasi guru terhadap prestasi belajar siswa. Sedangkan variabel lingkungan sekolah mempunyai pola hubungan tidak langsung dengan prestasi belajar siswa yang diperantarai oleh variabel motivasi berprestasi guru. Hubungan langsung antara variabel lingkungan sekolah dengan prestasi belajar siswa tidak signifikan maka jalur hubungannya dapat dihilangkan dan tidak perlu untuk digambar.

\section{Pembahasan}

Pembahasan hasil analisis jalur mengikuti hipotesis yang diajukan sebelumnya.

Pengaruh langsung dan tidak langsung kompetensi manajerial kepala sekolah terhadap prestasi belajar siswa.

Dari prosedur analisis jalur di atas menunjukkan bahwa terdapat hubungan langsung antarkompetensi manajerial ke- pala sekolah dengan prestasi belajar siswa walaupun konstribusinya hanya 5,523\%. Hal ini menunjukkan bahwa hubungan yang terjadi antara kompetensi manajerial kepala sekolah dengan prestasi belajar siswa adalah hubungan positif. Meskipun kompetensi manajerial kepala sekolah berhubungan positif namun kontribusinya dalam menjelaskan prestasi akademik adalah rendah. Hubungan kompetensi manajerial kepala sekolah dengan prestasi belajar siswa cukup besar jika melalui motivasi berprestasi guru yaitu sebesar 32,094\%. Hal ini menunjukkan bahwa kompetensi manajerial kepala sekolah merupakan dasar penentu kebijakan dan manajemen sekolah yang dapat meningkatkan prestasi belajar siswa melalui penekanan pada aspek peningkatan motivasi guru. Secara keseluruhan kompetensi manajerial kepala sekolah baik secara langsung maupun tidak langsung melalui motivasi berprestasi di SMA Muhammadiyah Kota Yogyakarta mempunyai kontribusi efektif sebesar $37,617 \%$. Hubungan kompetensi manajerial kepala sekolah dengan prestasi belajar siswa sesuai dengan hipotesis yang diajukan yang berbunyi "Terdapat hubungan langsung antara kompetensi manajerial kepala sekolah, dengan prestasi belajar siswa SMA Muhammadiyah di Kota Yogyakarta" dan hipotesis yang diajukan yang berbunyi "Terdapat hubungan tidak langsung antara kompetensi manajerial kepala sekolah terhadap prestasi belajar siswa SMA Muhammadiyah di Kota Yogyakarta melalui motivasi berprestasi guru."

Pengaruh langsung dan tidak langsung lingkungan sekolah terhadap prestasi belajar siswa.

Hasil pengujian dengan menggunakan prosedur analisis jalur diperoleh bahwa lingkungan sekolah tidak mempunyai hubungan yang signifikan secara langsung dengan prestasi belajar siswa, akan tetapi mempunyai hubungan yang signifikan terhadap prestasi belajar siswa melalui motivasi berprestasi guru, walaupun kontribusinya sangat kecil yaitu 1,039\%. Hal ini menunjukkan bahwa lingkungan seko- 
lah tidak dapat menjelaskan pengaruhnya terhadap prestasi belajar siswa. Rendahnya sumbangan lingkungan sekolah terhadap prestasi belajar siswa diduga karena lingkungan sekolah sebagian besar SMA Muhammadiyah Kota Yogyakarta dari sisi luas sekolah sesungguhnya tidak memenuhi syarat.

Dalam pengamatan peneliti lingkungan sekolah SMA Muhammadiyah Kota Yogyakarta hanya SMA Muhammadiyah 1 dan SMA Muhammadiyah 2 saja yang mempunyai luas representatif. Di beberapa sekolah bahkan memiliki beberapa kampus atau lokasi gedung untuk kegiatan pembelajaran sehingga memerlukan mobilitas yang cukup tinggi untuk berpindah dari kampus satu ke kampus lain. Letak sekolah yang berada di pinggir jalan utama Kota Yogyakarta seperti SMA Muhammadiyah 3, SMA Muhammadiyah 4, SMA Muhammadiyah 6 dan SMA Muhammadiyah 7 menjadikan sekolah terlalu bising dan dapat mengganggu proses pembelajaran. Hal ini yang menyebabkan lingkungan sekolah tidak signifikan memberikan sumbangan secara langsung terhadap prestasi belajar siswa, jikalaupun ada hubungan positif melalui variabel motivasi berprestasi guru tetapi sangat rendah sehingga tidak dapat menjelaskan tentang prestasi belajar siswa. Hubungan lingkungan sekolah dengan prestasi belajar siswa tidak sesuai dengan hipotesis yang diajukan yang berbunyi "Terdapat hubungan langsung antara lingkungan sekolah, dengan prestasi belajar siswa SMA Muhammadiyah di Kota Yogyakarta" dan sesuai dengan hipotesis yang diajukan yang berbunyi "Terdapat hubungan tidak langsung lingkungan sekolah terhadap prestasi belajar siswa SMA Muhammadiyah di Kota Yogyakarta melalui motivasi berprestasi guru."

Pengaruh langsung motivasi berprestasi guru terhadap prestasi belajar siswa.

Hasil pengujian hipotesis mengenai hubungan langsung antara motivasi berprestasi guru dengan prestasi belajar siswa menggunakan prosedur analisis jalur me- nunjukkan bahwa indeks korelasi yang tinggi. Dengan demikian hasil penelitian ini menerima hipotesis yang menyatakan bahwa terdapat hubungan positif antara motivasi berprestasi guru dengan prestasi belajar siswa. Konstribusi motivasi berprestasi guru terhadap prestasi belajar siswa sebesar $47,060 \%$, hal ini menunjukkan bahwa kontribusi tersebut sangat besar. Dengan melihat adanya korelasi positif antara motivasi berprestasi guru dengan prestasi belajar siswa maka dapat diartikan bahwa makin tinggi motivasi berprestasi guru maka makin tinggi prestasi belajar siswa yang akan dicapai. Oleh karena SMA Muhammadiyah Kota Yogyakarta perlu melakukan berbagai upaya untuk meningkatkan motivasi berprestasi guru. Hubungan motivasi berprestasi guru dengan prestasi belajar siswa sesuai dengan hipotesis yang diajukan yang berbunyi "Terdapat hubungan langsung antara motivasi berprestasi guru, dengan prestasi belajar siswa SMA Muhammadiyah di Kota Yogyakarta".

Dari prosedur analisis jalur di atas dapat diketahui bahwa kompetensi manajerial kepala sekolah, lingkungan sekolah dan motivasi berprestasi guru berhubungan dengan prestasi belajar siswa baik secara langsung maupun tidak langsung. Terdapat satu variabel yang tidak mempunyai hubungan langsung dengan prestasi belajar siswa yaitu lingkungan sekolah. Dengan demikian variabel lingkungan sekolah dengan pola langsung tidak dapat digunakan untuk menjelaskan prestasi belajar siswa.

Selanjutnya jika dicermati lebih jauh dari prosedur analisis jalur yang memiliki sumbangan efektif tertinggi adalah variabel motivasi berprestasi guru. Dengan demikian berarti di antara variabel kompetensi manajerial kepala sekolah dan motivasi berprestasi guru, yang paling berpengaruh dalam menjelaskan prestasi belajar siswa adalah motivasi berprestasi guru.

Dari uraian tersebut dapat ditarik makna bahwa di SMA Muhammadiyah Kota Yogyakarta, motivasi berprestasi guru merupakan kunci dalam mewujudkan 
prestasi belajar siswa. Oleh karena itu perbaikan mutu atau kualitas pendidikan di SMA Muhammadiyah Kota Yogyakarta perlu bertolak pada peningkatan motivasi berprestasi guru yang pada akhirnya dapat meningkatkan prestasi belajar siswa, sedangkan variabel lain seperti kompetensi manajerial kepala sekolah, lingkungan sekolah merupakan variabel pendukung, walaupun begitu tidak dapat diabaikan perannya dalam upaya peningkatan prestasi belajar siswa sebagai tujuan penting bagi penyelenggaraan pendidikan.

\section{Simpulan dan Saran}

Simpulan

Berdasarkan data hasil penelitian yang maka dapat disimpulkan sebagai berikut:

Terdapat pengaruh langsung antara kompetensi manajerial kepala sekolah, dengan prestasi belajar siswa SMA Muhammadiyah di Kota Yogyakarta, dengan konstribusi efektif sebesar 5,52\%.

Terdapat pengaruh tidak langsung antara kompetensi manajerial kepala sekolah terhadap prestasi belajar siswa SMA Muhammadiyah di Kota Yogyakarta melalui motivasi berprestasi guru, dengan sumbangan efektif sebesar 32,09\%.

Tidak Terdapat pengaruh antara lingkungan sekolah dengan prestasi belajar siswa SMA Muhammadiyah di Kota Yogyakarta.

Terdapat pengaruh tidak langsung antara lingkungan sekolah terhadap prestasi belajar siswa SMA Muhammadiyah di Kota Yogyakarta melalui motivasi berprestasi guru dengan sumbangan efektif sebesar $1,04 \%$.

Terdapat pengaruh langsung antara motivasi berprestasi guru dengan prestasi belajar siswa SMA Muhammadiyah di Kota Yogyakarta, dengan sumbangan efektif sebesar 47,06\%.

Sumbangan secara keseluruhan, variabel kompetensi manajerial kepala sekolah, lingkungan sekolah, dan motivasi berprestasi guru memberikan sumbangan yang cukup besar terhadap variabel pres- tasi belajar siswa, sebesar 85,71\%, dan pengaruh di luar variabel kompetensi manajerial kepala sekolah, lingkungan sekolah dan motivasi berprestasi guru sebesar $14,29 \%$.

Saran

Berdasarkan kesimpulan hasil penelitian yang dirumuskan di atas, maka diajukan beberapa saran sebagai berikut:

\section{Untuk Pemerintah}

Demi peningkatan kualitas pendidikan secara adil dan merata, maka pemerintah juga dituntut memberikan perhatian pada sekolah-sekolah swasta khususnya dalam upaya peningkatan kompetensi manajerial kepala sekolah, lingkungan sekolah dan motivasi berprestasi guru.

\section{Untuk sekolah dan majelis DIKDASMEN \\ Muhammadiyah Kota Yogyakarta}

Berdasarkan hasil penelitian, diketahui bahwa kompetensi manajerial kepala sekolah dan motivasi berprestasi guru mempunyai pengaruh yang sangat besar dalam pencapaian prestasi belajar siswa, jadi diharapkan dapat meningkatkan prestasi belajar siswa adalah dengan meningkatkan kualitas kepala sekolah dan guru di sekolah Muhammadiyah.

Untuk Kepala sekolah, hasil penelitian ini kiranya dapat menjadi masukan untuk terus berusaha menciptakan iklim yang kondusif melalui peningkatan kompetensi manajerial kepala sekolah dalam mengelola sekolah sehingga dapat mewujudkan pencapaian prestasi belajar siswa dan tujuan sekolah.

Untuk Guru SMA Muhammadiyah di Kota Yogyakarta, hasil penelitian ini kiranya dapat dijadikan bahan refleksi untuk terus berusaha meningkatkan motivasi berprestasi dalam bekerja dalam melaksanakan tugas sebagai guru dalam proses belajar menagajar di sekolah.

\section{Bagi peneliti}

Mengembangkan dan menyempurnakan penelitian mengenai prestasi belajar siswa dengan melibatkan variabel lain se- 
lain kompetensi manajerial kepala sekolah, lingkungan sekolah dan motivasi berprestasi guru yang diperkirakan mampu memberikan kontribusi yang dapat meningkatkan prestasi belajar siswa seperti faktor intern (fisik \& psikis) siswa, faktor keluarga, pemerintah dan masyarakat. Disamping itu diharapkan dapat menggunakan metode, observasi, wawancara mendalam dan tes kinerja.

Membandingkan kompetensi manajerial kepala sekolah, lingkungan sekolah dan motivasi berprestasi guru antara sekolah swasta dengan sekolah negeri sebab ada perbedaan antara sekolah negeri dan swasta, baik pada input siswa maupun pada pengelolaan manajemen sekolah. Dengan membandingkan sekolah swasta dan negeri maka akan mendapatkan masukkan yang baik untuk menentukkan kebijakan dalam kerangka meningkatkan mutu pendidikan di Indonesia.

\section{Daftar Pustaka}

Aan Komariah \& Cepi Triatna. (2006). Visionary leadership menuju sekolah efektif. Jakarta; BumiAksara

Anwar Prabu Mangkunegara. (2008). Perilaku dan budaya organisasi. Bandung: Rafika Aditama.

Armstrong, T. (2009). Academic achievement and the concept of success. diambil pada tanggal 10 Juni 2012 http://www.moneyinstructor.com $\angle$ doc/academicsuccess.thomasarm07/03/2009.asp

Armstrong, M. (2009). Armstrong's handbook of management and leadership : a guide to managing for results. Philadelphia: Kogan Page Limited

Boddy, D. (2008). Management an introduction. London: Prentice Hall

Depdiknas. (2003). Undang-Undang RI Nomor 20 Tahun 2003, tentang Sistem Pendidikan Nasional.

Enco Mulyasa. (2011). Menjadi kepala sekolah profesional. Bandung: PT Remaja Rosda Karya.
Ernie Tisnwati Sule \& Saeful Kurniawan. (2008). Pengantar manajeman. Jakarta : Prenada Media Group

Husaini Usman. (2011). Manajemen teori, praktik, dan riset pendidikan. Jakarta: Bumi Aksara.

Irwanto, dkk. (2002). Psikologi umum. Jakarta: Prenhallindo.

Lunenburg, F. C and Ornstien A. C. (2000). Educational administration: concepts and practices. USA: Wadsworth

McNergney, R. F. \& Carrier, C. A (1981). Teacher Development. New York: Macmillan Publishing Co. Inc.

Michel, S.et. al. (1996). Academic success. Diambil pada tanggal 13 November 2011, http//cals-cf.calsnet.arizona.edu/ fcs/bpy/content.cfm? content=academic _succes.

Ngalim Purwanto. (2011). Psikologi pendidikan. Bandung: PT Rosdakarya

Nurkencana. (2005). Evaluasi Hasil Belajar Mengajar. Surabaya: Usaha Nasional.

Oemar Hamalik. (2008). Kurikulum dan pembelajaran. Jakarta: PT Bumi Aksara.

Schneider, M. (2002). Do school facilities affect academic outcomes? National clearinghouse facilities. Diambil pada tanggal 11 Juli 2012, dari http://www.edfacilities.org/pubs/ outcomes.pdf /

Sri Esti Wuryani Djiwandono. (2009). Psikologi pendidikan. Jakarta: PT Grasindo.

The World Health Organization's. (2002). The physical school environment, an essential component of a health promoting school (information series on school health document 2). Geneva: The World Health Organization's

User Usman. (2011). Menjadi guru profesional, Bandung: Rosda Karya. 